\title{
Capital Structures in German Small and Mid Caps: Does Trade-Off or Pecking Order Theory Explain Current Reality Better?
}

\author{
Klaus Dommes' ${ }^{1}$ Michael Schmitt ${ }^{2 *}$, Elmar Steurer ${ }^{3}$ \\ ${ }^{1}$ Commerzbank AG, Frankfurt am Main, Germany \\ ${ }^{2}$ International School of Management, Frankfurt am Main, Germany \\ ${ }^{3}$ Hochschule Neu-Ulm, Neu-Ulm, Germany \\ Email: *michael.g.schmitt@ism.de
}

How to cite this paper: Dommes, K., Schmitt, M., \& Steurer, E. (2019). Capital Structures in German Small and Mid Caps: Does Trade-Off or Pecking Order Theory Explain Current Reality Better? Journal of Financial Risk Management, 8, 147-162. https://doi.org/10.4236/jfrm.2019.83010

Received: July 11, 2019

Accepted: August 27, 2019

Published: August 30, 2019

Copyright $\odot 2019$ by author(s) and Scientific Research Publishing Inc. This work is licensed under the Creative Commons Attribution-NonCommercial International License (CC BY-NC 4.0). http://creativecommons.org/licenses/by-nc/4.0/ (c) (i) \& Open Access

\begin{abstract}
This paper analyzes the determinants of the capital structure of German companies. The data are based on the year-end values of 44 companies included in the SDAX for the 2017 financial year. The data are examined in a multiple regression analysis according to the ordinary least squares (OLS) method. The result basically shows a strong correlation for the market leverage ratio with the factors of company size and growth opportunities. Profitability plays only a subordinate role. No significant correlation with the capital structure of German companies in the SDAX has been found for the tangibility factor of the assets. Basically, the results of this work support trade-off theory more than pecking order theory and thus point to the existence of an optimal debt ratio.
\end{abstract}

\section{Keywords}

Capital Structure, Leverage Ratio, Trade-Off Theory, Pecking Order Theory, SDAX

\section{Introduction}

The investigation of the capital structure of companies has long been discussed both in business research and in the context of practical economic decisions. The focus has always been on optimization - the capital structure should be chosen in such a way that the associated capital costs are minimized. In their pioneering analyses, Modigliani and Miller (1958) show under specific assumptions that no optimal capital structure exists. Precisely because the determinants of an optimal 
capital structure are neither easy to identify nor unchangeable, companies and academia are constantly faced with the challenge of reviewing possible influencing factors. These influencing factors are not equally pronounced for every company but are subject to structural differences. A known difference is the size of the companies. While large companies find it easier to access the international capital market and various jurisdictions, small companies are more limited in their choice of possible forms of financing.

Economic policy measures can also be suitable for changing capital structures. The numerous measures taken by the EU to increase the portfolio of possible financing instruments for small and medium-sized enterprises (SMEs) are obvious (European Commission, 2013). Examples include the promotion of the SME bond market as well as measures to strengthen their equity capital base. Nevertheless, it remains to be understood how small and medium-sized companies receipt such measures. This work tries to add to the understanding of what drives the capital structure choice in Germany.

The result basically shows a strong correlation for the market leverage ratio with the factors of company size and growth opportunities. Profitability plays only a subordinate role. No significant correlation with the capital structure of German companies in the SDAX has been demonstrated for the tangibility factor of the assets. Basically, the results of this work support trade-off theory (TOT) more than pecking order theory (POT) and thus point to the existence of an optimal leverage ratio. The discussion will conclude with a summary and an outlook for further research, which may follow on from the results of this work.

\section{Capital Structure Theory}

\subsection{Development of Theories}

Since Modigliani and Miller (1958) laid the foundation for modern capital structure theory with the development of the irrelevance theorem, numerous theoretical and empirical studies have been published that build on it and analyze the influence of various determinants on the capital structure of companies in more detail. The discussion focuses on the question of the existence of an optimal capital structure, which managers use as a basis for their financial decisions. If such an optimal level of indebtedness were achieved, shareholder value would be maximized and the key financial and corporate objectives fulfilled. In addition, other fiscal policy objectives, such as ensuring stability and future growth, are directly affected by these decisions. Knowing about the influence of various factors on the capital structure can help management make capital structure decisions in favor of the company and the investors.

Over the years, two central theories have been established which answer the question of the existence of an optimal capital structure differently. TOT assumes the existence of an optimal capital structure. The later-developed POT rejects the existence of such an optimum. Although theoretical research has made some progress, it took a long time before initial studies attempted to prove 
empirically the influence of individual factors on capital structure (Rajan \& Zingales, 1995). Basically, a distinction is made between company-specific and macroeconomic determinants. Since the former are directly controllable by management, their importance for the financial manager is of particular interest. However, the results of these studies are often inconsistent. For example, while Rajan and Zingales (1995) found a negative relationship between the size and leverage of German companies, Börner, Grichnik, and Reize (2010) reported a positive one and Hall, Hutchinson, and Michaelas (2004) did not detect any significant relationship.

\subsection{Trade-Off Theory}

According to the early history of financing theory, any financing decision was thought not to be independent from the investment decision but a necessary prerequisite for their implementation. Fisher (1930), however, postulated the opposite in his Separation Theorem. According to Fisher (1930), a capital structure policy independent of investment decisions should be possible in a perfect capital market. Neoclassical financing theory builds on this assumption and attempts to explain financing decisions on the basis of cash flows.

The net present value of an entity can be determined by discounting its future cash flows. The discount rate applied here corresponds to the company-specific cost of capital. The TOT justifies the existence of an optimal capital structure in the event that the cost of capital is minimized.

Modigliani and Miller (1958) developed the irrelevance theorem named after them and thus not only laid the foundation for the TOT based on it, but also sparked a discussion that continues to this day about the relevance of various factors influencing the capital structure of companies. According to Modigliani and Miller (1958), in perfect capital markets the selection of the capital structure has no influence on the value of the company, since the weighted average cost of capital (WACC) does not change despite increasing indebtedness. Modigliani and Miller (1958) make tough assumptions:

- no taxes

- no transaction costs

- no information asymmetries

- managers act in the best interest of the equity investors

- companies cannot go bankrupt

- companies know their future financing needs.

For this perfect capital market model, Modigliani and Miller (1958) prove that the costs and benefits of rising debt balance.

Although the analysis of Modigliani and Miller (1958) has since been criticized many times for its unrealistic assumptions (Jensen \& Meckling, 1976; Stiglitz, 1969), it is today the starting point for modern financing theory. By gradually relaxing individual assumptions, the fundamental work of Modigliani and Miller (1958) allows for the influence of other factors on the capital structure to be determined. 
Kraus and Litzenberger (1973) extended the model to include insolvency costs. These correspond to the product of the probability of insolvency and the costs incurred in this case. Such costs include direct (e.g., litigation costs) and indirect (additional costs due to a suspicion of imminent insolvency by stakeholders) costs. The result of this work was later described by Myers (1984) as static TOT and describes the following relationship (see Figure 1).

The cost of equity which is represented by the top line in Figure 1 initially rises linearly. In the case of very high indebtedness, an exponential development can even be proven due to the increased insolvency risk. The same applies to the cost of debt which is the bottom line in Figure 1. The debt capital providers are affected by increasing indebtedness much later, as they are paid before the equity capital providers in the event of insolvency and their interest rates are guaranteed up to this point. Due to the lower risk debt capital providers bear their reward is lower. That is, why the cost of debt line is lower than the cost of equity line. The weighted average cost of capital line, which is represented by the middle line in Figure 1, is U-shaped. While the tax advantage of borrowed capital always has a positive effect, the insolvency costs are almost negligible when the debt ratio is low and only develop into a significant disadvantage as indebtedness progresses, which ultimately outweighs the tax savings. The total cost of capital is minimal for the point at which the marginal insolvency costs exceed the marginal tax benefit for the first time. Thus, there is an optimal level of indebtedness for which the enterprise value is at a maximum. Companies should try to approach this level in their capital structure decisions.

Since in reality there is no perfect capital market, further trade-off models were developed in the following years, taking into account agency costs, which attempt a more comprehensive and therefore more accurate explanation of empiricism (Jensen \& Meckling, 1976). These are assigned to the neo-institutionalist financing theory. Agency costs are those that arise from a principal-agent relationship. Due to incongruent goal sets, additional disadvantages for the principal may arise.

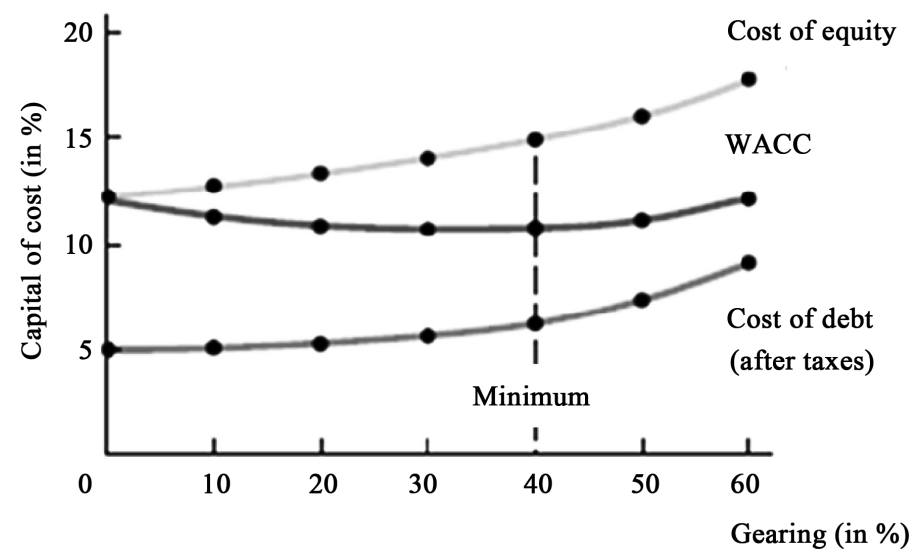

Figure 1. Cost of capital according to trade-off theory. Source: Author's own presentation based on Brigham and Houston (2013). 
The example of a company's owners and managers illustrates this, among other things, through the use of free cash flows. Managers value independence and control and therefore have an interest in keeping as high a proportion of the inflows as possible within the company, while owners prefer a payout to further diversify their personal portfolio. In addition, managers could invest in long-term unprofitable projects if they appear profitable in the short term to strengthen their position and receive potential bonuses. Borrowing would reduce these agency costs as the additional interest burden reduces free cash flows and creditors put additional pressure on managers to act in a disciplined manner.

Agency costs for debt capital, on the other hand, are incurred due to incongruent goal sets of equity and debt capital providers. While shareholders are generally in favor of riskier investments with high earnings potential, lenders and bondholders are more interested in secure investments that guarantee their interest payments. In the event of impending insolvency, there is a particularly wide divergence of interests, as the lenders are paid first but have no decision-making power. Managers could invest in highly speculative projects in the interests of shareholders and thus bet the assets due to creditors.

\subsection{Pecking Order Theory}

The POT is an alternative explanation for corporate financing decisions. For example, it can be observed that announcements of capital increases often lead to price slumps on the stock market. This can hardly be explained by the TOT. In contrast to TOT, the POT is based on a fixed ranking of financing types according to their popularity among managers. There would be no optimal capital structure.

In the same year, both Leland and Pyle (1977) and Ross (1977) investigated so-called signaling effects, taking information asymmetries into account. Accordingly, existing shareholders have insider information which they do not share with new investors if this would be detrimental to them. This moral hazard is priced by the new investors in form of discounts. However, management's participation in the success of the company is viewed positively by the debt holders. For example, it can be assumed that a manager who participates in the success of an investment only decides in favor of it if it appears profitable, even if inside information is taken into account.

Myers and Majluf (1984) developed the well-known POT based on findings from agency cost and signaling theory. They show that rationally acting investors interpret management financing decisions as signals of an over- or undervaluation of the company. For example, a management that, on the basis of inside information, considers the entity to be overvalued would prefer to raise equity to share future losses with new investors. New investors react accordingly by claiming a considerable discount when buying shares. Conversely, if the future outlook for a company is bright, existing shareholders will not want to share potential residual gains with new investors. In this case, they will abstain from 
raising equity. The POT thus explains the frequently observed phenomenon of price declines when announcing capital increases. As management anticipates this effect it prefers internal financing instruments to external ones and debt to equity in order to avoid sending negative signals. These preferences are shown in Figure 2.

\subsection{Empirical Findings in Literature}

Since none of the above theories can sufficiently explain reality, empirical studies on the significance of individual factors on the capital structure have been carried out for decades. This allows the development of independent hypotheses for the different factors. The relationships between several impact factors and leverage ratio can in turn be justified by the different theoretical models and contribute to clarifying the contradictions between them. Such factors may be either company-specific or macroeconomic in nature. On the contrary, the significance of the factors depends strongly on the type of enterprise, the nature of the industry and the economic environment (Mokhova \& Zinecker, 2014).

One of the most prominent studies was conducted by Rajan and Zingales (1995). In this study, the authors examined almost 8000 companies from the G7 countries with regard to various influencing factors (size, return, growth potential, tangibility of assets). They carried out different regressions for different definitions of leverage (including market and book values of equity). Surprisingly, they show that companies from Great Britain and Germany have the lowest proportion of debt capital. The predominant opinion at that time was that companies in Anglo-American countries were less indebted than those in continental Europe and Japan, as the equity culture of these countries differed greatly. Significant influence factors on the leverage ratio of German companies would be their size and growth possibilities (negative) as well as the tangibility of the assets (positive). The negative correlation between size and debt-equity ratio is particularly striking here, as it is contrary to the correlations in all other countries. It also contradicts the findings of Harris and Raviv (1991), which show a positive correlation.

Hall et al. (2004) carried out a regression for SMEs from eight European countries. They differentiated between the long-term (LTD) and short-term

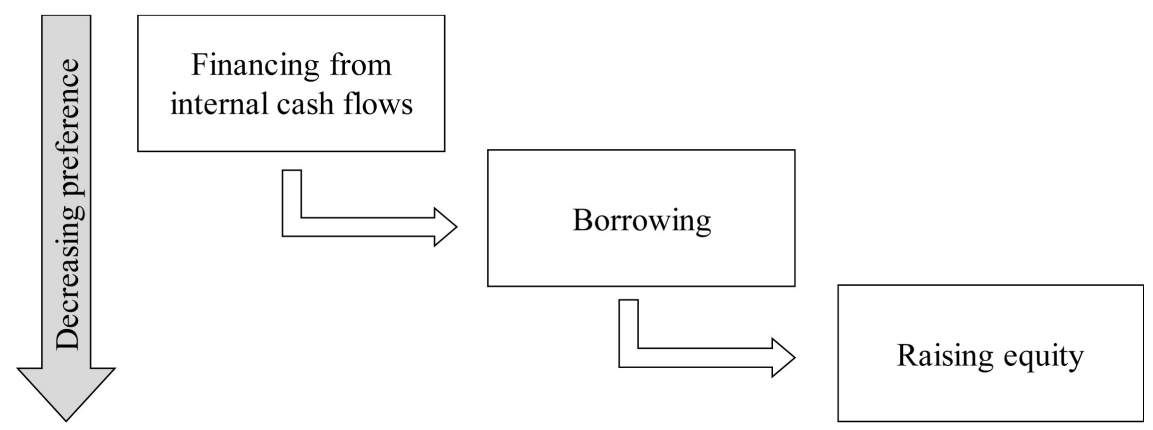

Figure 2. Managers' preferences according to the pecking order theory. Source: Author's own presentation based on Baskin (1989). 
(STD) leverage ratios and noted differences in the importance of the factors on the different ratios. Only the tangibility of the assets has a significant influence on the LTD leverage ratio in German companies. In contrast, the STD ratio is additionally determined by profitability. Although the results for the size factor are different, they are insignificant for both cases.

Börner et al. (2010) showed for German SMEs that the size, age and tangibility of investments correlate positively with the debt-equity ratio, while free float and profitability counteract this. Furthermore, the form of the company (corporation/partnership) has no significant influence on the capital structure.

In summary, it is noticeable that some of the empirical results for German firms coincide (e.g., tangibility of assets, profitability). At the same time, different impacts are obtained for other factors (e.g., size, growth opportunities). As a focus, the effect of the size of the company is highlighted. According to Rajan and Zingales (1995), this has a negative effect on the leverage ratio, according to Börner et al. (2010), it has a positive effect, and according to Hall et al. (2004), it has no significant effect at all. Therefore, the current relationship of size and leverage is yet to be understood.

\subsection{Development of Hypotheses}

Based on the theoretical models and empirical research, hypotheses are derived for the proposed impact on the debt-to-equity ratio in German companies. For the reasons given above, other company-specific factors are taken into account in addition to the size attribute, for which a connection with the leverage ratio was often demonstrated in earlier studies (Harris \& Raviv, 1991; Rajan \& Zingales, 1995). In some cases, different hypotheses can be derived for the application of TOT and POT.

\subsubsection{Company Size}

According to the TOT, there is a positive correlation with the leverage ratio for the size of the company in the focus of this work. Large companies are generally more diversified and have easier access to different types of financing. Therefore, if size is seen as a proxy for business risk, the insolvency costs of debt should decrease as the size increases, as the risk also decreases. This kind of relationship has also been found earlier in literature, too (Harris \& Raviv, 1991; Fama \& French, 2002; Dang, 2013).

$\mathrm{H1}$ : There is a positive relationship between size and leverage ratio according to TOT.

The POT mostly argues here that large companies need to inform the public and their shareholders more extensively and that information asymmetries therefore decrease with increasing size. As a result, the significance of the signaling effect and therefore the incentive for managers to prefer other sources over external equity is also diminishing (Rajan \& Zingales, 1995). According to the POT, there is a negative correlation between size and leverage ratio of a company. Such relationship was found by Faulkender and Petersen (2006). 
$\mathrm{H} 2$ : There is a negative relationship between size and leverage ratio according to POT.

\subsubsection{Growth Potential}

As a rule, growing companies have a higher capital requirement than non-growing ones. According to the POT, managers will cover these needs first through internal funds and then through borrowing. As a result, fast-growing companies would have to borrow more because of their high capital requirements, for which the internally generated cash flows are insufficient. At the same time, companies in growing markets generally have many financing possibilities, so that managers can resort to their preference for debt capital for a long time before they have to make use of equity capital. Harris and Raviv (1991) also suspect a positive correlation.

H3: According to POT, there is a positive correlation between a company's growth potential and its leverage ratio.

At the same time, growth potential may have been acquired through M\&A and result in intangible assets such as goodwill. As explained below, according to TOT, intangible assets correlate negatively with the debt-equity ratio. The results of Rajan and Zingales (1995) confirm this assumption.

H4: According to TOT there is a negative correlation between the growth potential and the leverage ratio of a company.

\subsubsection{Profitability}

According to POT, the profitability of a company should correlate negatively with the level of indebtedness. More profitable companies generate higher annual cash flows and therefore have less reason to draw on external funds. This relationship has also been empirically observed (Harris \& Raviv, 1991; Rajan \& Zingales, 1995).

H5: According to POT, there is a negative correlation between a company's profitability and its leverage ratio.

At the same time, however, more profitable companies are also exposed to less risk than unprofitable ones. For example, the rating of a company depends, among other things, on the interest cover ratio. Rising operating cash flows lead to an improvement in the ratio, and borrowing becomes cheaper. In addition, for companies with high profitability, the agency costs between owners and managers for the use of free cash flows are correspondingly higher. Raising outside capital reduces this problem by burdening profits with additional interest.

H6: According to TOT and agency cost theory, there is a positive correlation between a company's profitability and leverage ratio.

\subsubsection{Tangibility of Assets}

Tangible assets such as machinery and land as well as financial assets are well suited as collateral for loans and thus have a positive effect on the risk incurred by the lender. Intangible assets such as goodwill, rights and licenses or software, 
on the other hand, are only suitable as collateral to a limited extent. This is due to the fact that intangible assets are generally more difficult to value and are subject to greater fluctuations in value. Therefore, the cost of debt should be lower for companies with a high tangibility of assets than for those with a lot of intangible assets.

H7: According to the TOT, there is a positive correlation between the tangibility of a company's assets and its leverage ratio.

No hypothesis can be derived from the POT regarding this issue.

\section{Empirical Analysis Based on German SDAX Companies}

\subsection{Data Base}

The following section examines the significance of various impact factors for the leverage ratio of German small and mid-cap companies. We retrieved our data from the Refinitiv Eikon database. Data from 44 companies which were listed in the SDAX as at 31.12.2017 are evaluated. The SDAX comprises the 50 largest companies that are not already listed in the DAX or MDAX. The admission of companies to the SDAX is subject to listing in the Prime Standard, a legally regulated stock exchange segment of the Frankfurt Stock Exchange. This is accompanied by compliance with special international transparency requirements. For example, companies listed in the Prime Standard must adhere to international accounting standards (IFRS or US-GAAP), publish detailed interim reports in German and English at the end of the first and third quarters of the financial year, and publish their ad-hoc announcements in English.

The decision in favor of the SDAX as the index including the smallest companies of the Prime Standard also includes an attempt to gain new insights through the analysis of data which were considered comparatively less frequently. In addition, the SDAX lists a total of 50 companies, six of which are not suitable for our analysis due to their business activities in the financial sector for which additional GAAP legislation applies. Excluding them enables the evaluation of data on a largely homogeneous basis.

German companies are traditionally very heavily leveraged. The central financial instrument is the bank loan. In this context, we are therefore also talking about a bank-oriented financial system. Anglo-American countries have a more open-minded equity culture. These systems are referred to as market-oriented. However, Rajan and Zingales (1995) shows that UK companies are also largely debt financed and that there are no major differences between the US and other G7 countries. Therefore, any interrelations found for German companies could also apply to other countries.

To calculate a relationship between several influencing factors and a dependent variable, a regression analysis is usually performed in addition to an analysis of variance (ANOVA). In contrast to ANOVA, regression goes beyond determining the significance of the overall context and allows each individual factor to be evaluated according to its importance for the model. 


\subsection{Operationalization of Variables}

Only the operationalization of the dependent and independent variables mentioned in the hypotheses allows an analysis by means of a regression since these are otherwise not measurable.

Many possible definitions remain for the leverage ratio, as the measured variables can be varied in different ways. ${ }^{1}$ Rajan and Zingales (1995) discuss the advantages and disadvantages of different leverage definitions. In doing so, they assume the broadest operationalization of total liabilities/total assets and make further adjustments. Firstly, they specify that debt and equity ratios should be based on consolidated values, otherwise distortions caused by intra-group loans and shareholdings will distort the leverage ratio of the parent. As this paper evaluates data from group reports prepared in accordance with IFRS, these are already consolidated figures. In addition, Rajan and Zingales (1995) make adjustments in respect of intangible assets and deferred taxes because these distort the international comparison of companies due to local differences. Since only German companies are considered in this work, these adjustments are superfluous here as well.

However, the above definition also includes non-interest-bearing debt, such as liabilities to suppliers. These have no real financing function and should therefore not be taken into account, otherwise they artificially increase the leverage ratio. The resulting ratio is debt/capital. In addition, a company's liquidity further increases its leverage. However, at least short-term debts may be netted directly with the cash held in the cash register. Various industries or other external circumstances could affect a company's liquidity requirements. Since liquidity management in this case has nothing to do with capital structure decisions, they should not be taken into account here. Therefore, cash and cash equivalents are deducted from liabilities in both the denominator and the numerator (net debt/net capital).

When considering equity, Rajan and Zingales (1995) distinguish between book and market values. Although most empirical studies of this kind (especially on SME data) only consider book values for simplicity reasons (Hall et al., 2004; Börner et al., 2010), it is quite possible that managers base their capital structure decisions on market leverage. The market capitalization describes the actual value of a company as better than the book value of the equity due to the valuation of the future potential. Thus, in this paper the market capitalization of the equity capital is used for the analysis.

Usually, the natural logarithm from sales is used as a proxy for the size of a company (Rajan \& Zingales, 1995; Gaud, Jani, Hoesli, \& Bender, 2005; Daszyns-

${ }^{1}$ By default, the leverage ratio of a company is expressed by the total liabilities/total capital ratio. However, other possibilities are also conceivable, such as the flow parameter EBIT to interest expense (Aghion \& Bolton, 1992). The latter is applied when leverage is considered as a benchmark for the transfer of control in financial difficulties (from owners to creditors). In this case, the decisive factor is whether a company can pay its fixed costs. In this work, however, the advantages and disadvantages associated with debt capital in the long term are at the forefront. Therefore, the more common definition of total debt/total capital is used. 
ka-Zygadlo \& Szpulak, 2012). However, the total value of assets, i.e. the balance sheet total, is also typically used (Hall et al., 2004). In this paper, the balance sheet total is used as a measure of size since the relationship between sales and size is strongly dependent on the sector.

The growth potential of a company is usually expressed by a ratio of market and book values (Rajan \& Zingales, 1995). Since the potential of a company is not reflected in the book value of its equity but ideally in its market capitalization, this operationalization seems logical. In addition, the ratio of market to replacement values (Tobin's Q) (Huang \& Song, 2006) or annual sales growth (Hall et al., 2004) is sometimes used. However, this work makes use of the first mentioned proxy from market values at book value, as this has widely been used in the past.

The profitability of a company is probably easier to operationalize than the other attributes due to clearly defined formulas. The return on assets is used as standard for this purpose (Francfort \& Rudolph, 1992; Rajan \& Zingales, 1995; Gaud et al., 2005). The return on assets tends to correlate strongly with the balance sheet total of the company, so that this figure is also not appropriate due to multicollinearity (Hall \& Weiss, 1967; Shepherd, 1972; Lee, 2009). The absolute measure of net income is therefore used in this paper as a measure of profitability.

The tangibility of the assets results from the quotient tangible assets/total assets. This definition is also used almost exclusively in other studies (Rajan \& Zingales, 1995; Hall et al., 2004; Daszynska-Zygadlo \& Szpulak, 2012).

\subsection{Results and Discussions}

The following interpretations assume a clear cause-and-effect direction in the contexts arising from the regressions. But in reality this does not have to exist in this form. For example, the multiple regression model assumes that a dependent variable is influenced by several independent variables. However, this causality is based solely on the assumptions made prior to regression analysis. In this case, it is assumed that size, profitability, asset tangibility and growth opportunities influence a company's leverage ratio but not vice versa. These assumptions are based on derivations from theoretical models like TOT and POT and on the results of other empirical work.

In addition, a third factor, which is not even taken into account in this model (i.e. industry), could also influence these two variables, and there could therefore be no direct causal relationship between size and leverage ratio. Therefore, the results of multiple regression are not unambiguous.

\subsubsection{Result with Four Explanatory Variables}

In the first model, the leverage ratio is measured as the ratio of interest-bearing debt capital to the market value of equity capital and is explained by the independent variables size as "balance sheet total", growth potential via market to book values, profitability as "net income" and tangibility of assets as the ratio of tangible assets to total assets using the year-end values of 2017 (see Table 1). 
Table 1. Model with four explanatory variables.

\begin{tabular}{ccc}
\hline & Coefficients & $P$-value \\
\hline Intersect & $-1.405^{* * *}$ & 0.0030 \\
Log assets & $0.128^{* * *}$ & 0.0001 \\
Growth opportunities & $-0.020^{* *}$ & 0.0262 \\
Net income & $-4.7649 \mathrm{E}-07^{*}$ & 0.0638 \\
Asset tangibility & 0.0766 & 0.5286 \\
Coefficient of determination & & 0.590 \\
Adjusted coefficient of determination & & 0.548 \\
Observations & & \\
\hline
\end{tabular}

${ }^{*}$ : Significance at the $10 \%$ level; ${ }^{* *}$ : Significance at the $5 \%$ level; ${ }^{* *}$ : Significance at the $1 \%$ level.

The result provides interesting insights. On the one hand, the model as a whole meets ambitious significance requirements. The coefficient of determination of 0.59 indicates that the four independent variables used satisfactorily explain the leverage ratio. The adjusted coefficient of determination, which also takes into account the number of explanatory variables, is 0.55 , only insignificantly lower. It can be concluded that there is a considerable relationship between the predictors presented here and the leverage ratios at market values.

Three of the four factors are of significant importance in explaining the leverage ratio. The individual details are discussed as follows:

It is noteworthy that the relationship between company size and leverage ratio in this study is positive and highly significant at the $99 \%$ level. This contradicts the results of Rajan and Zingales (1995), according to which, the size of the company has a negative impact on the leverage ratio. A look at the assumptions underlying the work of Rajan and Zingales (1995) reveals the negative correlation they found. According to the POT, there is a negative correlation between the size and leverage ratio of a company since larger companies are usually subject to higher transparency requirements, and information asymmetries between managers and creditors are therefore minimized. As a result, the signaling effect of raising equity capital is becoming less significant and managers no longer prefer debt capital over external equity capital. However, the companies examined in this study are subject to similarly high transparency requirements due to their listing in the Prime Standard, irrespective of their individual size. It is therefore not surprising that there is no negative correlation for this specific sample that may exist in smaller companies. Conversely, it can even be concluded that larger companies tend to make more use of debt capital, with the positive sensitivity found here confirming the TOT theory.

In addition, it is noticeable that the growth opportunities correlate strongly and negatively with the leverage ratio of the companies at a significance level above 95\%. These results are in part consistent with the findings of Rajan and Zingales (1995), who also show a negative correlation between growth and leve- 
rage of German companies. Accordingly, the risk-oriented explanation of the TOT outweighs the reasoning by the POT, namely that growing companies generally have more financing needs and managers primarily resort to debt capital. Instead, the growth opportunities as intangible assets are comparatively less suitable as collateral, which increases the average borrowing costs of companies. Companies with higher growth opportunities can therefore only benefit for a shorter period from the tax shield of debt capital before the disadvantages outweigh this effect.

For profitability measured as net income, another significant negative influence on the company's leverage ratio can be demonstrated in this paper although the significance is relatively low at the $90 \%$ level. This finding provides a confirmation of the POT by assuming a negative correlation. More profitable companies generate higher annual cash flows and therefore tend to increase their internal financing, which tends to reduce the leverage ratio.

The tangibility of the assets is positively related to leverage, as suggested by TOT, but not at a significant level. Interestingly, for growth opportunities, which are also a form of intangibles, some models show a much greater relation with the leverage ratio. This is partly due to the fact that growth opportunities are not or hardly taken into account in the operationalization for the tangibility of the assets: only goodwill of entities in which the parent has an interest, but not the original goodwill of the parent itself is recorded on the balance sheet in accordance with IFRS. At the same time, growth opportunities are on average much greater than the intangibles actually recorded on the balance sheet. A possible correlation between the tangibility of a company's assets and its leverage ratio could therefore be seen in the correlation between growth opportunities and the leverage ratio. Finally, it should be noted that the tangibility of the assets does not contribute to clarifying the overall spread.

It is also possible that there are further influencing factors which are not considered here and which correlate with the regressors. This possibility is indicated by the high significance of the constant-this fact typically goes hand in hand with the presence of missing variables. It would be conceivable, for example, that both size and profitability would strongly depend on the company's industry. Such a dependency would also explain the comparatively low correlation between profitability and the company's leverage ratio. The companies examined in this study belong to a total of 16 different sectors, so that a sector significance might be present.

\subsubsection{Result with Three Explanatory Variables}

The next step is to try to optimize the model statistically. Therefore, the variable tangibility is omitted due to a lack of explanatory power.

The adjusted measure of determination of the optimized model with three variables (Table 2) is slightly increased compared to the model with four variables with 0.555 compared to 0.548 . This proves that it makes sense to remove the variable tangibility from the model. The sensitivities and significance of the 
Table 2. Model with three explanatory variables.

\begin{tabular}{ccc}
\hline & Coefficients & $P$-value \\
\hline Intersect & $-1.353^{* * *}$ & 0.0033 \\
Log assets & $0.129^{* * *}$ & 0.0001 \\
Growth opportunities & $-0.0197^{* *}$ & 0.0276 \\
Net Income & $-4.3527 \mathrm{E}-07^{*}$ & 0.0765 \\
Coefficient of determination & 0.586 \\
Adjusted coefficient of determination & 0.555 \\
Observations & 44 \\
\hline
\end{tabular}

${ }^{*}$ : Significance at the $10 \%$ level; ${ }^{* *}$ : Significance at the $5 \%$ level; ${ }^{* *}$ : Significance at the $1 \%$ level.

variables used are similar to those of the four-factor model. However, it must be noted that the significance has only improved slightly for the variable size. In principle, it can be said that this model is well suited for transfer into practice since all explanatory factors can be easily found in the annual financial statements or on the basis of market data. Thus, this model can certainly be used in practice for strategic decisions on capital structure.

\section{Summary}

The results of this work provide a mixed picture. The proposed four-factor model is statistically significant overall at an attractive level. When interpreting the statistical explanation of the individual variables, it is noticeable that two variables support the TOT, while two other variables advocate for the POT.

According to TOT, companies aim for an optimal leverage ratio, which results from the trade-off of the advantages and disadvantages of debt capital for the point at which the weighted average costs of capital are minimized. Due to lower costs of debt, this optimal gearing ratio for larger companies is achieved when the leverage ratio is higher than for smaller companies. In addition to size, growth opportunities also have an impact on companies' leverage ratios. The highly significant negative relationship found supports the TOT. On the other hand, the POT is proposed by a significant negative correlation between the variable profitability and leverage ratio. However, the statistical significance for this relationship was lower than the links between size and growth opportunities on leverage. In addition, the lack of statistical significance for the asset tangibility variable is an indication in favor of the POT. Finally, the statistical significance of relationships supporting TOT was stronger than the relationships assumed by POT. Thus, companies seemingly tend to base capital structure decisions on TOT rather than POT.

It is important to note that every piece of research has limitations, and so has ours. First of all, we analyzed a short time frame only. However, our contribution provides a current flashlight on a long-lasting discussion on a still not well understood phenomenon. Moreover, our sample is limited to German small and mid-cap 
companies, and therefore might encounter specificities. Further, our results above were gathered by analyzing corporates belonging to the non-financial sector. Thus, a variety of other sectors encompassing very different business models such as industrials or service companies are still contained in the data set. Thus, contentwise, the results of this work can be followed up by examining the influence of the industry factor on the leverage ratios of companies. This could help understand the findings of this work in a wider context.

\section{Conflicts of Interest}

The authors declare no conflicts of interest regarding the publication of this paper.

\section{References}

Aghion, P., \& Bolton, P. (1992). An Incomplete Contracts Approach to Financial Contracting. The Review of Economic Studies, 59, 473-494. https://doi.org/10.2307/2297860

Baskin, J. (1989). An Empirical Investigation of the Pecking Order Hypothesis. Financial Management, 18, 26-35. https://doi.org/10.2307/3665695

Börner, C., Grichnik, D., \& Reize, F. (2010). Finanzierungsentscheidungen mittelständischer Unternehmer-Einflussfaktoren der Fremdfinanzierung deutscher KMU. Schmalenbachs Zeitschrift für betriebswirtschaftliche Forschung, 62, 227-275. https://doi.org/10.1007/BF03377359

Brigham, E. F., \& Houston, J. F. (2013). Fundamentals of Financial Management (13th ed.). Mason, $\mathrm{OH}$ : South-Western, Cengage Learning.

Dang, V. A. (2013). Testing Capital Structure Theories Using Error Correction Models: Evidence from the UK, France and Germany. Applied Economics, 45, 171-190. https://doi.org/10.1080/00036846.2011.597724

Daszynska-Zygadlo, K., \& Szpulak, A. (2012). The Determinants of Corporate Debt Ratios in Chosen European Countries. Economics and Management, 17, 62-68. https://doi.org/10.5755/j01.em.17.1.2252

European Commission (2013). Aktionsplan Unternehmertum 2020: Den Unternehmergeist in Europa neu entfachen (COM 2012/0795).

https://eur-lex.europa.eu/legal-content/EN/TXT/PDF/?uri=CELEX:52012DC0795\&fro $\underline{\mathrm{m}=\mathrm{EN}}$

Fama, E. F., \& French, K. R. (2002). Testing Trade-Off and Pecking Order Predictions about Dividends and Debt. Review of Financial Studies, 15, 1-33. https://doi.org/10.1093/rfs/15.1.1

Faulkender, M., \& Petersen, M. A. (2006). Does the Source of Capital Affect Capital Structure? The Review of Financial Studies, 19, 45-79.

https://doi.org/10.1093/rfs/hhj003

Fisher, I. (1930). The Theory of Interest. New York: Macmillan.

Francfort, A. J., \& Rudolph, B. (1992). Zur Entwicklung der Kapitalstrukturen in Deutschland und in den Vereinigten Staaten von Amerika: Eine vergleichende empirische Untersuchung. Schmalenbachs Zeitschrift für betriebswirtschaftliche Forschung, 44, 1059-1079.

Gaud, P., Jani, E., Hoesli, M., \& Bender, A. (2005). The Capital Structure of Swiss Companies: An Empirical Analysis Using Dynamic Panel Data. European Financial Man- 
agement, 11, 51-69. https://doi.org/10.1111/j.1354-7798.2005.00275.x

Hall, C. G., Hutchinson, P. J., \& Michaelas, N. (2004). Determinants of the Capital Structures of European SMEs. Journal of Business Finance, 31, 711-728. https://doi.org/10.1111/j.0306-686X.2004.00554.x

Hall, M., \& Weiss, L. (1967). Firm Size and Profitability. Review of Economics and Statistics, 49, 319-331. https://doi.org/10.2307/1926642

Harris, M., \& Raviv, A. (1991). The Theory of Capital Structure. The Journal of Finance, 46, 297-355. https://doi.org/10.1111/j.1540-6261.1991.tb03753.x

Huang, G., \& Song, F. M. (2006). The Determinants of Capital Structure: Evidence from China. China Economic Review, 17, 14-36. https://doi.org/10.1016/j.chieco.2005.02.007

Jensen, M. C., \& Meckling, W. H. (1976). Theory of the Firm: Managerial Behavior, Agency Cost and Ownership Structure. Journal of Financial Economics, 3, 305-360. https://doi.org/10.1016/0304-405X(76)90026-X

Kraus, A., \& Litzenberger, R. H. (1973). A State-Preference Model of Optimal Financial Leverage. The Journal of Finance, 28, 911-922. https://doi.org/10.1111/j.1540-6261.1973.tb01415.x

Lee, J. (2009). Does Size Matter in Firm Performance? Evidence from US Public Firms. International Journal of the Economics of Business, 16, 189-203. https://doi.org/10.1080/13571510902917400

Leland, H. E., \& Pyle, D. H. (1977). Informational Asymmetries, Financial Structure, and Financial Intermediation. The Journal of Finance, 32, 371-387. https://doi.org/10.2307/2326770

Modigliani, F., \& Miller, M. H. (1958). The Cost of Capital, Corporation Finance and the Theory of Investment. The American Economic Review, 48, 261-297.

Mokhova, N., \& Zinecker, M. (2014). Macroeconomic Factors and Corporate Capital Structure. Procedia-Social and Behavioral Sciences, 110, 530-540. https://doi.org/10.1016/j.sbspro.2013.12.897

Myers, S. C. (1984). The Capital Structure Puzzle. The Journal of Finance, 39, 574-592. https://doi.org/10.1111/j.1540-6261.1984.tb03646.x

Myers, S. C., \& Majluf, N. S. (1984). Corporate Financing and Investment Decisions When Firms Have Information That Investors Do Not Have. Journal of Financial Economics, 13, 187-221. https://doi.org/10.1016/0304-405X(84)90023-0

Rajan, R. G., \& Zingales, L. (1995). What Do We Know about Capital Structure? Some Evidence from International Data. The Journal of Finance, 50, 1421-1460. https://doi.org/10.1111/j.1540-6261.1995.tb05184.x

Ross, S. A. (1977). The Determination of Financial Structure: The Incentive-Signalling Approach. The Bell Journal of Economics, 8, 23-40. https://doi.org/10.2307/3003485

Shepherd, W. G. (1972). The Elements of Market Structure. Review of Economics and Statistics, 54, 25-37. https://doi.org/10.2307/1927492

Stiglitz, J. E. (1969). A Re-Examination of the Modigliani-Miller Theorem. The American Economic Review, 59, 784-793. 